(C) 2020 International Journal of Nursing and Midwifery Science (IJNMS)

This is an Open Access article distributed under the terms of the Creative Commons Attribution 4.0 International License which permits unrestricted non-commercial use, distribution, and reproduction in any medium, provided the original work is properly cited. http://ijnms.net/index.php/ijnms ORIGINAL RESEARCH

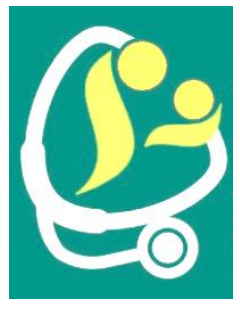

\title{
ANALYSIS OF COGNITIVE ABILITIES OF SCHOOL-AGE CHILDREN BASED ON EATING HABITS AND NUTRITIONAL STATUS
}

\author{
Tri Peni, Siti Indatul Laili, Esti Dwi Jayanti, Dwi Anggita Sari
}

Stikes Bina Sehat PPNI Mojokerto

Email : peni.ners@gmail.com, sitiindatullaili@yahoo.co.id, estidwi599@gmail.com, dwianggita754@gmail.com

\section{ABSTRACT}

Keywords

Eating habits are behaviors that are appropriate for the selection of the right foods so that they will provide a good nutritional status. Nutrients that consist of macronutrients such as carbohydrates, proteins, fats, and micro substances such as vitamins and minerals needed by the body for the process of growth and development. The purpose of this study was to determine the relationship between eating patterns with the nutritional status and cognitive abilities of elementary school children. Cross-Sectional research design. The population in this study were all students as many as 367 students, the sampling used was a Stratified random sampling technique, a sample of 192 respondents. Data analysis uses the Spearman Rank Rho statistical test. The results of the analysis of dietary variables with nutritional status were obtained $\rho(0.003)<\alpha$ $(0.05)$, so $\mathrm{H} 0$ was rejected, meaning that there was a relationship between eating habits and nutritional status of school-age children, with a value of $r=0.210$ which showed a high positive correlation. The results of the analysis of nutritional status variables with cognitive abilities obtained results $\rho=0.00,<\alpha=0.05$. meaning that there is a relationship between nutritional status and cognitive learning achievement in elementary school children. Normal nutritional status can be obtained by applying a positive diet so that the intake that enters the body in accordance with the needs of the body. Children who have normal nutritional status have good cognitive abilities. Parents are the most important support in optimizing children's growth and development

\section{INTRODUCTION}

School-age children are in dire need of nutrients consisting of macronutrients such as carbohydrates, proteins, fats, and micro-substances such as vitamins and minerals. These substances are needed by the body for the process of growth and development. (Devi, 2012).In school-age children who play a lot outside the home, high physical activity requires a good and nutritious food intake. Most of the time a child is in school during the day his food intake is not controlled. Children at school prefer snacks, so children will choose their own food without thinking about food content and good and bad food. When school-age children experience excess consumption of energy-rich foods the child will experience obesity, besides the behavior of children eating unhealthy snacks will experience malnutrition (Hardinsyah \& Nyoman, 2016). 
The good nutritional status will affect children's achievement in cognitive aspects with regard to intellectual learning attitudes consisting of knowledge and understanding. Children can master the various knowledge they receive as in the learning process children can receive and respond to their thoughts. The more thoughts and ideas a child has, the richer and broaden the child's cognitive mind area (Djamarah, 2011).

The results of the study (Malongane, 2017) in the Capricorn District school of Limpopo Province, South Africa, found that children who were underweight in boys were $9.5 \%$ and girls were $7.8 \%$. The prevalence of stunting for boys is $11.3 \%$ while girls are $7.4 \%$. Whereas for good attendance at schoolboys are $3.6 \%$, girls $4.2 \%$. In Indonesia, the prevalence in 2018 children aged 6-12 years is classified as very short and is classified as very short $30.8 \%$. While the prevalence of thin and very thin is $10.2 \%$. The prevalence of malnutrition and malnutrition is $17.7 \%$. The prevalence of fat is $8.00 \%$ (Riskesdas, 2018). In East Java, the prevalence in 2018 children aged 6-12 years was classified as very short and classified as very short $32.2 \%$. While the prevalence of thin and very thin is $6.00 \%$. The prevalence of malnutrition and malnutrition is $16.8 \%$. The prevalence of fat is $10.4 \%$. (Riskesdas, 2018).

Purwani research results (2013) in the Posyandu of Kabunan Village, Taman District, Pemalang Regency, from 33 respondents showed that 18 respondents (54.5\%) who had a good diet found 15 children in the normal category and 3 obese children. Respondents who have a poor diet, as many as 15 respondents found 12 thin children, 2 normal children, and 1 obese child. Research (Herlina, 2014) in Sibolga City State Elementary School showed that the majority of children with good nutrition status were 56 people (89\%) and the majority had good learning achievement as many as 56 people $(89 \%)$. While the results of the study (Wahyuningsih, 2012) in Primary school Kadilanggo Wedi Klaten most of the respondents had good nutritional status as many as 17 respondents (56.7\%) and most of the good children's learning achievements were 20 respondents (66.7\%).

Eating patterns that exceed the body's needs will cause overweight otherwise a poor diet will cause the body to become thin. Both of these conditions are just as bad, so they are called malnutrition (Kementerian Kesehatan, 2014). The normal nutritional status will affect the work function balance of the body's organs. In general, children experience weight gain and height in one year. The increase shows that the nutritional needs of the child's body including energy, protein, minerals, vitamins, and fluids are fulfilled. Good nutritional status or optimal nutritional status occurs when the body gets enough nutrients that are used efficiently, so as to enable physical growth, brain development, workability and general health at the highest level possible (Almatsier, 2009).

Parents who tend to be less observing their children's behavior in consuming snacks must change their thinking because snacks consumed by the child will determine the child's nutritional status (Hardinsyah \& Nyoman, 2016). Consuming good and balanced nutrition is increasing the quality of human resources. The nutritional status and achievement index is a picture of what is consumed by primary school children in the long run, which can be either malnutrition or over nutrition. Nutrients such as carbohydrates, proteins, and other nutrients, especially iron, in the body's metabolism play a role in the thought process or the process of 
reasoning and concentration power and are

\begin{tabular}{|c|c|c|c|c|}
\hline No & Variable & Category & (F) & $(\%)$ \\
\hline \multirow{2}{*}{1} & \multirow{2}{*}{ Gender } & Male & 88 & 45.8 \\
\hline & & Girl & 104 & 54.2 \\
\hline \multirow{4}{*}{2} & \multirow{4}{*}{$\begin{array}{c}\text { Parental } \\
\text { education }\end{array}$} & $\begin{array}{c}\text { Primary } \\
\text { School }\end{array}$ & 22 & 11.5 \\
\hline & & $\begin{array}{l}\text { Middle } \\
\text { school }\end{array}$ & 47 & 24.5 \\
\hline & & High school & 103 & 53.6 \\
\hline & & College & 20 & 10.4 \\
\hline 3 & $\begin{array}{c}\text { History of } \\
\text { illness }\end{array}$ & Healthy & 101 & 52.6 \\
\hline
\end{tabular}

\begin{tabular}{|c|c|c|c|c|}
\hline & & Fever & 33 & 17.2 \\
\hline & & Common cold & 23 & 12.0 \\
\hline & & Cough & 18 & 9.4 \\
\hline & & Imflammation & 17 & 8.9 \\
\hline 4 & & Positive & 106 & 55.2 \\
\hline & & Negative & 86 & 44.8 \\
\hline 4 & $\begin{array}{c}\text { Nutritional } \\
\text { status }\end{array}$ & Very thin & 7 & 3.6 \\
\hline & & Thin & 21 & 10.9 \\
\hline & & Normal & 117 & 60.9 \\
\hline & & Fat & 30 & 15.6 \\
\hline & & Obesity & 17 & 8.9 \\
\hline 5 & $\begin{array}{l}\text { Cognitive } \\
\text { abilities }\end{array}$ & Graduated & 143 & 74.5 \\
\hline & & Not pass & 49 & 25.5 \\
\hline & Total & & 192 & 100 \\
\hline
\end{tabular}

very closely related to the efficiency of learning. (Waryono, 2010).

The purpose of this study was to analyze eating habits with nutritional status and cognitive abilities in school-age children at Pohkecik Elementary School

\section{METHODS}

This research was conducted on 25 February - 2 March 2018. This research used a cross-sectional method. The population in this study were all students in grades 1-6 at Pohkecik Elementary School, namely 367 students. Sampling using a stratified random sampling technique. The sample used in this study were 192 students from grades 1-6 at Pohkecik Elementary School. Eating habit is measured using a questionnaire. Nutritional status is determined based on BMI according to age, while cognitive abilities use cognitive value data on report cards. Data analysis uses the Spearmen rho statistical test.

\section{RESULT}

Table 1. Characteristics of respondents based on Gender, Parental Education, History of illness, Eating habits, Nutrition Status, Cognitive Ability in School-age Children

Based on table 1 shows that the majority of respondents were female as many as 101 respondents $(52.6 \%)$. Characteristics of respondents based on parental education show that almost half of respondents with high school education are 103 respondents $(53.6 \%)$. Characteristics of respondents based on a history of illness showed that the majority of respondents based on a history of illness were not sick as many as 101 respondents $(52.6 \%)$. Characteristics of respondents based on eating patterns mostly have positive eating patterns (55.2\%). Nutritional status shows that the majority of respondents have normal nutritional status $(60.9 \%)$. Characteristics of respondents based on cognitive abilities showed that most respondents had cognitive abilities with graduation criteria of 143 respondents (74.5\%). 
Table. 2 Cross Tabulation of Eating habits with Nutritional Status of School-Age Children on February 28 at Pohkecik Elementary School in Dlanggu District, Mojokerto Regency

\begin{tabular}{|c|c|c|c|c|c|c|}
\hline \multirow{3}{*}{$\begin{array}{l}\text { Nutritional } \\
\text { status }\end{array}$} & \multicolumn{4}{|c|}{ Eating habits } & \multirow{2}{*}{\multicolumn{2}{|c|}{ Total }} \\
\hline & \multicolumn{2}{|c|}{ Positive } & \multicolumn{2}{|c|}{ Negative } & & \\
\hline & $\mathrm{F}$ & $\%$ & $\mathrm{~F}$ & $\%$ & $\mathrm{~F}$ & $\%$ \\
\hline Very thin & 1 & 0.5 & 4 & 2.1 & 5 & 2.6 \\
\hline Thin & 0 & 0 & 12 & 6.3 & 12 & 6.3 \\
\hline Normal & 97 & 51 & 32 & 16.7 & 129 & 67.2 \\
\hline Fat & 6 & 3.1 & 26 & 13.5 & 32 & 16.7 \\
\hline Obesity & 2 & 1 & 12 & 6.3 & 14 & 7.3 \\
\hline Total & 106 & 55 & 86 & 44.8 & 192 & 100 \\
\hline $\begin{array}{l}\text { Bas } \\
\text { majority } \\
\text { habit with } \\
\text { responden }\end{array}$ & $\begin{array}{l}\text { on } \\
\text { tho } \\
\text { orme } \\
\left(51^{\circ}\right.\end{array}$ & he & able & shor & $\begin{array}{l}\text { tha } \\
\text { bod } e\end{array}$ & $\begin{array}{l}\text { the } \\
\text { ating } \\
\text { e } 97\end{array}$ \\
\hline
\end{tabular}

Table. 3 Cross Tabulation of Nutritional Status with cognitive of School-Age Children on February 28 at Pohkecik Elementary School in Dlanggu District, Mojokerto Regency

Table 3. It can be seen from the fact that most respondents with normal nutritional status with the cognitive ability

\begin{tabular}{|c|c|c|c|c|c|c|}
\hline & \multicolumn{4}{|c|}{ Cognitive Abilities } & \multirow{2}{*}{\multicolumn{2}{|c|}{ Total }} \\
\hline \multirow[t]{2}{*}{$\begin{array}{l}\text { Nutrition } \\
\text { al status }\end{array}$} & \multicolumn{2}{|c|}{ Graduated } & \multicolumn{2}{|c|}{ Not pass } & & \\
\hline & $\mathrm{F}$ & $\%$ & $\mathrm{~F}$ & $\%$ & $\mathrm{~F}$ & $\%$ \\
\hline $\begin{array}{l}\text { Very } \\
\text { thin }\end{array}$ & 0 & 0 & 7 & 3.64 & 7 & 3.64 \\
\hline Thin & 0 & 0 & $\begin{array}{l}2 \\
1\end{array}$ & $\begin{array}{c}10.9 \\
3\end{array}$ & 21 & $\begin{array}{c}10.9 \\
3\end{array}$ \\
\hline Normal & $\begin{array}{c}10 \\
7\end{array}$ & $\begin{array}{c}55.7 \\
2\end{array}$ & $\begin{array}{l}1 \\
0\end{array}$ & 5.20 & $\begin{array}{c}11 \\
7\end{array}$ & $\begin{array}{c}60.9 \\
3\end{array}$ \\
\hline Fat & 22 & $\begin{array}{c}11.4 \\
5\end{array}$ & 8 & 4.17 & 30 & $\begin{array}{c}15.6 \\
2\end{array}$ \\
\hline Obesity & 14 & 7.30 & 3 & 1.57 & 17 & 8.85 \\
\hline Total & $\begin{array}{c}14 \\
3\end{array}$ & $\begin{array}{c}74.4 \\
7\end{array}$ & $\begin{array}{l}4 \\
9\end{array}$ & $\begin{array}{c}25.5 \\
1\end{array}$ & $\begin{array}{c}19 \\
2\end{array}$ & 100 \\
\hline
\end{tabular}

with graduation criteria are 107 respondents $(55.72 \%)$ and respondents who are very nutritional status with cognitive learning achievement with the criteria of not passing are 7 respondents (3.64\%). That the more normal nutritional status, the better cognitive learning achievement.

The results of the Spearmen Rank (Rho) test conducted using SPSS (Statistical Package for the Social Princes ) version 22.0, the results of the pvalue $(0.003)<\alpha(0.05)$, then $\mathrm{H} 0$ is rejected and $\mathrm{H} 1$ is accepted, meaning there is a relationship between eating patterns and nutritional status, with a correlation coefficient of 0.210 , it shows a high relationship and a positive correlation. The results of the analysis of nutritional status with cognitive abilities obtained $\rho=0.00$, $<\alpha=0.05$ there is a relationship of nutritional status with cognitive learning achievement of school-age children, with a correlation coefficient level of -0.398 indicates a low correlation and negative correlation.

\section{DISCUSSION}

The results showed there was a relationship between eating patterns with the nutritional status of school-age children with a correlation coefficient of 0.210 indicating a high correlation and positive correlation. Most respondents have a positive (good) diet that has a normal nutritional status of 97 respondents (50.5\%). Normal nutritional status can occur because macronutrients and micronutrients are fulfilled. Macronutrient substances consist of energy needs for children determined by basal metabolism, age, physical activity, environmental temperature, and health. Nutrients that contain energy are called macronutrients and consist of protein, fat, and carbohydrates. Each gram of protein or carbohydrate contains 4 kilocalories, while each gram of fat contains 9 kilocalories. Protein requirements are said to be adequate if they contain all the essential 
amino acids in sufficient quantities, are easily digested and absorbed by the body. Then the protein given must be partly in the form of high-quality protein such as animal protein (Waryono, 2010).

A balanced diet, which is in accordance with needs accompanied by the selection of the right foods will give birth to a good nutritional status. Food intake that exceeds the body's needs will cause overweight and other diseases caused by excess nutrients. Conversely, food intake that is less than needed will cause the body to become thin and vulnerable to disease. Both of these conditions are just as bad, so they are called malnutrition. The state of malnutrition due to lack of food and underweight is a common thing in many regions or poor countries. Conversely, the state of malnutrition due to excessive consumption of nutrients is a new phenomenon that is increasingly widespread. This situation is mainly experienced by the upper-middle-class society, namely the emergence of obesity in children and urban adolescents with the economic category up (Sulistyaningsih, 2011).

Research (Husien, 2017) about the influence of eating habits and nutritional behavior on nutritional status in elementary school in children aged 10-12 years in Cairo found that there was a positive correlation between milk, fruit and vegetable intake and mother's education. Also, there is a positive correlation between the consumption of milk, fruits and vegetables and having daily mineral and vitamin requirements. The results of the study (Juan, 2006) by analyzing differences in dietary habits and nutritional status in school children in Spain stated that children left the Mediterranean diet for the product industry, full of calories and saturated fatty acids but low in the nutritional component, which contributed to obesity and increased cholesterol levels. Also, breakfast consumption has been identified as an important factor in the nutritional status of children and in Spain. In observers more and more percentage of children don't eat breakfast. Nutrition affects health throughout the life cycle. A cross-sectional descriptive study conducted at the Medical College of Lahore found a positive relationship between eating habits and hemoglobin levels. The relationship between regular breakfast intake with BMI and MUAC was also positive. Eating habits affect the nutritional status of adolescent women while skipping breakfast is associated with anemia. (Akhtar, Zareen and Sarmad, 2018)

Eating habits greatly affect the nutritional status of children because nutritional status is the impact of food intake that is normally consumed by children. If the child usually consumes nutritious food and is on time then the child will likely get normal nutritional status, conversely, if the intake of food consumed by children is not nutritious and irregular, it is likely that the child will experience malnutrition status or can be called more or less nutritional status. Diet here is a way to regulate food intake in accordance with the needs of the body, such as determining the type, amount, and food content. If the diet is well implemented, the body's intake will be controlled so that the body can get a balanced nutritional status.

The results of the study there are children who have a positive eating pattern but the nutritional status of fat is 6 respondents (3.1\%), which is mostly experienced by children who are female. The results of the interview found a girl who adopted a positive eating pattern but had a nutritional status due to the fat child did not do much physical activity. The child tends to like to do physical activities that do not spend much energy such as playing 
games, painting, and reading books. This is what causes children to get fat nutritional status, because the intake of food that enters the body as a source of energy is not all used by the body, so it is stored in the body in the form of fat. Fat will accumulate in the body and cause fat.

The results of the study also found that children who had positive eating patterns had a very underweight nutritional status of 1 respondent $(0.5 \%)$, which could be due to the child experiencing infection in the last 1 week so that the child had difficulty swallowing food that affects the intake of nutrients needed by the body not fulfilled.

Children who eat negative eating patterns but have a normal nutritional status of 32 respondents (16.7\%). In this study, it was found that the majority of those who practice negative eating habits are men. Negative eating patterns can mean the habit of consuming foods that contain excess fat, causing more nutrition. Fatty foods commonly consumed by boys are pizza, burgers and instant noodles. Men who have negative eating habits will not experience more nutritional status because when doing activities boys spend a lot of energy. Based on the results of the interviews found that most boys do a lot of physical activities that spend a lot of energy such as playing soccer and playing volleyball. So that men are rarely found in the accumulation of nutrients that can cause more nutrition because the source of nutrients that enter the male body will be converted into a source of energy.

The results showed that the majority of respondents whose normal nutritional status with cognitive abilities passed the criteria of 107 respondents (55.72\%). Spearman Rank (Rho) Correlation statistical test results obtained $\rho$ $=0.00,<\alpha=0.05$, meaning that there is a relationship between nutritional status and cognitive learning achievement in elementary school children in Pohkecik Elementary School in Dlanggu District, Mojokerto Regency. The more normal nutritional status, the better cognitive learning achievement. The cause of the occurrence of normal nutritional status comes from aspects of nutrition associated with brain growth and development, the level of intelligence and nutritional conditions of children at primary school age. The brain is a very perfect body structure and function, but the working power of the brain and its fitness are very much influenced by the adequate supply of nutrients needed for the implementation of various brain functions (Waryono, 2010).

The good nutritional status will affect children's learning achievement on cognitive aspects with regard to intellectual learning attitudes consisting of knowledge and understanding. Children can master the various knowledge they receive as in the learning process children can receive and respond to their thoughts. The more thoughts and ideas a child has, the richer and broaden the child's cognitive realms (Djamarah, 2011). This is in accordance with research (Wahyuningsih, 2012) shows that there is a relationship between nutritional status and cognitive learning achievement, the better the nutritional status, the better the learning achievement of a child. Meanwhile according to research (Wulandini, 2017) shows that there is a relationship between nutritional status and cognitive learning achievement. The nutritional status will affect one's intelligence level and one's ability to capture lessons at school, so someone who has good nutritional status will have a better grasp and can get good achievements in his school. Conversely, if someone has a nutritional status that is less or more will have an impact on intelligence so that it is 
less optimal in capturing lessons in school so that learning achievement is not good.

Pay attention to nutrition by maximizing the intake of fish, fruits, vegetables, nuts, and grains that contain some $\mathrm{B}$ vitamins, vitamin $\mathrm{D}$, vitamin $\mathrm{E}$, antioxidants and Omega-3 fatty acids, which the brain needs, will improve cognitive abilities (Tucker, 2016). Research (Neuroscience et al., 2013), with observational shows that micronutrients can play an important role in children's cognitive development. However, the results of the intervention test using a single micronutrient cannot be concluded. More generally, there is evidence that malnutrition can impair cognitive development, while breastfeeding seems to be beneficial for cognition. Eating breakfast is also beneficial for cognition

Nutritional status is an important factor that affects learning achievement in a child, balanced and sufficient nutritional intake greatly affects one's intelligence in the same school age. With adequate nutrition intake, in other words, a good nutritional status will increase the concentration of learning and memory of children, children can receive lessons well so as to obtain cognitive learning achievement above the average value.

The results of the study of respondents who had normal nutritional status but did not pass the cognitive learning achievement were $5.20 \%$. In this study children who had normal nutritional status but did not pass their learning achievements were caused because the child was lazy to learn, a child who was conserving (apathetic) towards science tended to take a learning approach that was simple and not exhaustive. Students who lack positive encouragement and motivation from their parents will affect the enthusiasm or excitement it oflearning, so the desired goals are not achieved. The unfavorable environment also greatly determines the growth and development of children that affect children's learning achievement, if the conditions of the surrounding environment are not conducive then the child is unable to increase learning motivation and in the learning process, the child is unable to achieve optimal achievement.

The results obtained by respondents who have a very thin nutritional status with cognitive learning achievement with the criteria of not passing as many as 7 respondents and underweight nutritional status with cognitive learning achievement with the criteria of not passing as many as 21 respondents.

The low nutritional status of children will affect the growth process of children not growing according to their potential, while in the production of child energy becomes lazy and feels weak. In the body's defense if the immune system and antibodies are reduced the child is susceptible to infection, lack of nutrition in the structure and function of the brain can affect mental development so that the ability to think is low and malnourished children exhibit uneasy behavior (Almatsier, 2009).

Children who are susceptible to illness then, the body's immune system will comply with a decrease in appetite will result in reduced nutritional input in the body. In this case, the body does not have a lot of supply of nutrients needed for the implementation of various brain functions so that it affects the decreased concentration in the learning process. Because the lower the nutritional status of children, the more does not pass the cognitive learning achievement

. The results obtained by respondents who have the nutritional status of obese with cognitive learning achievement with 22 graduation criteria and respondents who 
have the nutritional status of obesity with cognitive learning achievement with graduation criteria as many as 14 respondents. Children at this age are generally able to choose and determine what foods they like and which are the best and which are not. However, these children choose the wrong foods even more if the parents do not give instructions to the child. The habit of eating snacks for children who choose the wrong foods such as instant foods and many containing dyes and preservatives will worsen the nutritional situation of children. Because these foods can interfere with children's health (Waryono, 2010).

In the results of this study child who have the nutritional status of obesity and obesity get the full attention of parents, because parents are very important, here parents begin to pay attention to the daily nutritional intake consumed by children. Parents give direction to the child to do activities that can reduce the child's weight. In the process of learning children also get motivation and full support, even though the nutritional status is fat or obese, parents also want to see their children excel while at school. Therefore parents provide extra tutoring outside of school.

\section{CONCLUSIONS}

The eating habits of school-age children in Elementary School Pohkecik, Dlanggu Sub-district, Mojokerto Regency are mostly in good eating habits, and their nutritional status is mostly normal. There is a relationship between eating habits and nutritional status of school-age children. A good child's diet causes the child's nutritional status to be normal.

There is a relationship between nutritional status and cognitive abilities of elementary school children. Respondents whose normal nutritional status had cognitive abilities passed criteria. With the adequate intake of nutrition causes a good nutritional status will increase the concentration of learning and memory of children. Children can receive lessons well so that they have cognitive abilities above the average value.

\section{REFERENCES}

Almatsier, S. (2009). Prinsip Dasar Ilmu Gizi. Jakarta: Gramedia Pustaka Utama.

Akhtar, N., Zareen, H. and Sarmad, R. (2018) 'Research Article Eating Habits and Nutritional Status of Female Students of a Medical College of Lahore', pp. 2-6.

Badan Penelitian dan Pengembangan Kesehatan. (2014). Hasil Riskesdas 2013.pdf. Laporan Nasional 2013.https://doi.org/1 Desember 2013

Depkes, R. (2010). Kepmenkes RI No.1995

Tahun 2010 Tentang Standar Antropometri Penilaian Status Gizi Anak. Jakarta: http://doi.org/10.1016/j.eneco.2014.11. 003

Devi, N. (2012). Gizi anak sekolah. Jakarta: PT.Kompas Media Nusantara.

Djamarah, S. (2011). Psikologi Belajar. Jakarta: PT. Rineka Cipta.

Hardinsyah, \& Nyoman, S. I. D. (2016). Ilmu Gizi Teori \& aplikasi. Jakarta: EGC

Husien H.A (2017) 'Effect of Food Habits on the Nutrional Status of Children in Cairo. Biomedical Statistic and informatics. Vol.2 No.1, 2017,pp.1017. doi:10.11648/j.bsi.20170201.13

Herlina. (2014). Hubungan Status Gizi Dengan Prestasi Siswa Sekolah Dasar Negeri 081234 Kota Sibolga Tahun 2014. Wahana Informasi, 4(1). https://doi.org/2089-8592

Juan, P. M. F. S. (2006) 'Dietary habits and nutritional status of school aged children in Spain', 21(3), pp. 374-378. 
Kementerian Kesehatan. (2014). Pedoman PGSKesehatan, 1-99.

Malongane, F. (2017). Nutritional status of children on the National School Nutrition Programme in Capricorn District, Limpopo Province South Africa, 11(1), 11-15. https://doi.org/10.7196/SAJCH.2017.v $11 \mathrm{i} 1.1124$

Neuroscience, H. et al. (2013) 'The role of nutrition in children' $s$ neurocognitive development from pregnancy through childhood', 7(March),pp.116.doi:10.3389/fnhum.2013.00097.

Sulistyoningsih, H. (2011). Gizi Untuk Kesehatan Ibu Dan Anak. Yogyakarta: Graha ilmu

Tucker, K. L. (2016) 'Nutrient intake nutritional status , and cognitive function with aging', 1367, pp. 3849. doi: 10.1111/nyas.13062.

Wahyuningsih, En. (2012). Hubungan Status Gizi dengan Prestasi Belajar Pada Anak Kelas V SDN 01 Kadilanggon Wedi Klaten. Involusi Kebidanan, 4(8), 47-59. Retrieved from

file:///C:/Users/User/Downloads/245729-1-PB.pdf

Waryono, S. (2010). Gizi Reproduksi. Yogyakarta: Pustaka Rihama.

Wulandini S, D. M. (2017). Hubungan Status Gizi dengan Prestasi Siswa di SDN 010 Pangkalan Kerinci Kabupaten Pelalawan. Menara Ilmu, XI(78), 92-100. 